Mirjana V. Bobić ${ }^{\text {, }}$

University of Belgrade,

Faculty of Philosophy

Department of Sociology

Belgrade (Serbia)
UDC 316.346-058.51(497.11)"2011"

314.117-058.51(497.11)"2011"

Review scientific paper

Submitted 13/10/2019

Revised 01/11/2019

Accepted 01/11/2019

doi:10.5937/socpreg53-23495

\title{
SOCIODEMOGRAPHIC PROFILE OF HOMELESS IN SERBIA ${ }^{2}$
}

Abstract: This is one of the rare papers on the homeless in Serbia, aimed to feature their sociodemographic profile. Main source of data is population census and the basic method is statistic. In addition,we apply secondary analysis of few qualitative researches, the findings of which were used as complementary. As a result, we present that vast majority of homeless are men, younger and middle aged, unmarried, with poor education and performing elementary occupations. Many of them are Roma and immigrants from the region and returnees from the EU as well. The interpretation of the findings, preempted by short overview of the social context of this phenomenon in Serbia and partly in EU, contributed to a conclusion which summarizes the profile of homeless and indicates onto an intervention targeted to pull them out of the social margin but also prevent further falls of many persons under risk.

Keywords: Homeless, Serbia, Socio-demographic profile, Social construction of the phenomenon, Social exclusion.

\section{Introduction: Basic Concepts and Goals}

Homelessness is a very complex problem of huge social deprivation (Bobić, 2014). First and foremost, it is closely related to the lack of housing or inadequate housing and then overall poverty as two basic dimensions of social exclusion. Homeless lack human resources: income, employment, assets, savings, skill sets, education,cultural capital and social respect (Jugović, Luković, 2012). Homeless do not possess social capital since they are usually abandoned by spouses and family, relatives, neighbors, friends, colleagues, members of local communities, ethnic groups, etc. They miss coping strategies and ways how to overcome multiple challenges of living in a risky society. Homelessness is therefore a passive response and a maladaptation to a mixture of unfavorable events in a life course and the outcome of false personal choices.

\footnotetext{
${ }^{1}$ mirjana.bobic@gmail.com

2 The paper is the result of the author's work on the project "Izazovi nove društvene integracije $u$ Srbiji: koncepti i akteri" ("The Challenges of New Social Integration in Serbia: Concepts and Actors") carried out by the Institute for sociological research, Faculty of Philosophy, from 2011 and funded by Ministry of Education, Science and Technological Development, Republic of Serbia (No 179035).
} 
Homeless people face crucial turning points in their lives, which make them roofless, without a job, in poor health and alone. Homelessness is often a result of the shrinking of welfare state and a social protection, especially in the Southern Europe, as well as in countries of post-socialistic transformation, unlike Scandinavian states with more generous policies. The decline of a support from family has nowadays become a result of second demographic transition, in short, changed attitudes toward marriage and family and their lower propensity (Bobić\&Vukelić, 2011). Widespread dissolution of families presupposes rise in numbers/ shares of single, divorced, widowed, one-parent families, elderly households, etc. On the other hand, not rarely entire families are being pushed at the social margin, due to armed conflicts and migrations, as was the case with ex-Yugoslav republics in 1990s, with refugees, internally displaced persons (arriving in central Serbia and Vojvodina from Kosovo and Metohija in 2000s), etc.

The risks of becoming a homeless are manifold: (long term) unemployment, lack of income and resources, poor education and related difficulties in access to work force. In the EU homeless have also been vastly recruited out of undocumented or unresolved nationality or citizenship status (immigrants, asylum-seekers, illegal aliens, persons without residence papers), (Avramov, 2006)

Homeless denote people who are either located at or use services of homeless shelters, reception and drop-in facilities, safe houses, etc. Also, in the EU as well as in Serbia, the homeless have been permanently on the increase, due to growing population of the elderly in advanced ageing societies. Majority come from collective centers, penal institutions, psychiatric hospitals, in-patient clinics, prisons, etc. They are often being discharged but without a place to go, because they are usually rejected by their families and relatives, and therefore, forced to move back and forth in a vicious circle, from in-patient clinic /hospital/ prison to a shelter and back, under conditions of the decline of public social protection, financial restrictions, reforms of social protection, lack of partnership in between public and private actors in this domain, etc., (Žarković, Petrović \& Timotijević, 2012; Ljubičić, 2013, 2018).

In sociology there is a term 'underclass' which also covers homeless and has been coined in the Anglo-Saxon literature. It is a heterogeneous group, an outcome of a spatial and industrial reconstruction of capitalism, new processes of urbanization and reorganization of space, which often bring about displacing of entire groups or populations, not rarely creating the "poverty ghettos" (Wilson, 1989, according to: Tomanović, S. et al., 2014).

In order to overcome numerous and not small divergences in the conceptualization and interpretation of the phenomenon, which reflect varying social and spatial developments of welfare states and social protection across European states and regions, legal treatment, social rights, support measures, public attitudes, The European Federation of National Organisations Working with the Homeless (FEANTSA) ${ }^{3}$ set up the European Observatory in 1991. Its purpose was to facilitate data collection and knowledge creation on the homeless in the EU member states. A unique typology of homelessness and social exclusion - European Typology of Homelessness (ETHOS), (www.feantsa.org) has been designed. Other than housing as the most basic personal need, this typology embraces homeless as a multi-

${ }^{3}$ FEANTSA is the only European NGO exclusively focusing on homelessness, established in 1989. It gathers together over 130 member organizations from 30 countries, including 28 Member States. 
dimensional phenomenon (Avramov, D., 1995, 1996, 1999, 2002, Jovičić, 2011; Žarković, Petrović \& Timotijević, 2012; Jugović \& Luković, 2012):

- rooflessness (without a shelter of any kind, sleeping rough);

- houselessness (with a place to sleep but temporary in institutions or shelter);

- living in insecure housing (threatened with severe exclusion due to insecure tenancies, eviction, domestic violence);

- living in inadequate housing (in caravans on illegal campsites, in unfit housing, in extreme overcrowding).

The enlisted criteria denote an 'umbrella concept' which actually covers different groups of people, who are not able to provide for a private, permanent and good-quality housing owing to personal resources, due to both financial and other social barriers. The true is that these people are not able to live decently and independently and therefore need permanent care and assistance, but not usually institutionalization (compare: Avramov, 1995, p. 72; Avramov,1996, p. 71).

In Serbia homelessness is still marginalized, without clear standards which would unequivocally define minimal housing conditions. That is why only relatively broad and insufficiently discriminatory notions and the 'primary'and the 'secondary'homeless are being applied (Žarković, Petrović \& Timotijević, 2012). In reality, in Serbia, there are at least three very broad and heterogeneous groups, representing either genuine homeless in line with the above stated EU conception, or people under major risk:

- The poor and numerous groups of households and people with no access to the housing market, especially to social housing, the broad category of so-called deprived social groups;

- very heterogeneous immigrant population from the beginning of the 1990's to date (military homeless, families of army personnel from the former Yugoslav republics, widows and children of killed/missed soldiers from the wars in ex-Yugoslavia in 1990's), refugees (from Croatia, Bosnia and Herzegovina), internally displaced population (from Kosovo and Metohija), and returnees coming from the EU under the Readmission Agreement;

- Roma ethnic group.

The volume and variety of homeless is Serbia is not negligible. To the contrary, if we rigorously apply the afore-mentioned typology (ETHOS), almost 10\% of the total population of the country would fall into homeless or people under permanent risk of homelessness (around 800-900,000, compare Žarković, Petrović \& Timotijević, 2014, p. 14).

Regrettably, Serbia misses a strategic, complex, systematic and coordinated plan of action against homelessness, which would also tackle the prevention for enormous categories of persons under risk.

The basic goal of this paper is portraying homeless in Serbia.Due to the lack of space, only mean socio-demographics will be presented while more thorough information could be found in some other works of the author (Bobić, 2014).

The paper is structured so that after the introductory chapter, we elaborate on the social context, followed by an explanation of data and method. The fourth chapter brings the discussion of the main results and the last one concludes by giving some practical and policy recommendations. 


\section{Social context}

Post-transitional Serbia is classified as European semi-periphery, hopelessly trying to catch up with the core countries of the EU as well as the rest of the globalized, developed world, the aim which is hard to be achieved ever (Blagojević Hughson, 2013). This insertion into neoliberal world system is strongly controlled by and stirred from international financial institutions (IMF, World Bank) by way of enforcing strict principles, such as: privatization, trade liberalization, promotion of foreign direct investments, fiscal discipline, tax reforms, increased efficiency of public expenses, financial liberalization, economic deregulation, flexibilization of work, etc. This so called 'normalization' and 'economic and political stabilization' which followed after 2000 (Lazić, 2011) and brought about high unemployment and rise of poverty for vast majority of citizens in Serbia, many of whom were previously employed in public sector (public administration, education, health, social protection, etc.). Some experts name this - 'de-development', the term borrowed from economists to depict the exploitation and devastation of human capital, institutions and the infrastructure in countries undergoing transition (Blagojević, 2013, p. 44). This is tightly related to overall social 'de-development' at the semi-periphery as well (Blagojević, 2013, p. 44), which is best described through dimensions such as: deindustrialization, increased poverty and social inequalities, intensive informalization of the economy, demise of social protection and rise of social vulnerability, depopulation, caused by both low fertility and high emigration, all of which have been coupled with deterioration of the quality of life, vast prevalence of the economy of survival, the permanent production of 'surpluses' of population, due to long term, high unemployment, underemployment, flexible work arrangements, downsizings and layoffs, etc.

Like in other countries of transformation, in Serbia too, homelessness is not a new phenomenon. Namely, it was already known in the socialism. Yet, homelessness was then hidden by the leading communist ideology, which accentuated social justice and solidarity for all. On the other hand, homelessness was also less visible due to the lack of housing as a result of the controversy of accelerated post WWII industrialization and slow urbanization. This contributed to the proliferation of 'mixed households' of people living in the countryside and working in the industry in nearby towns, many of whom resorted to building illegal suburban settlements, while others continued to live in multiple families under one roof in cities, etc. (cf. Timotijević, 2012, p. 42, Petrović, 2004, Milić et al., 1981). The posts-socialistic period added a "new" or transition-related homelessness (Timotijević, 2012) instigated by: housing transformation and privatization, decline in the construction of residential buildings, reduction and disappearance of social housing, inherited from socialism, increase in the prices of apartments in the cities and establishing high, market prices of housing, introducing mortgages and repossession of apartments on account of outstanding, unpaid bank loans and enormous housing costs. All these drawbacks are being combined and/or exacerbated by high and chronic unemployment, frequent job and property losses, increased family instability, family violence, alcoholism, drug abuse, etc. (Žarković, Petrović and Timotijević, 2012; Timotijević, 2012; Petrović, 2004, 2009).

Still, though quite evidently, homeless have been extremely devastated and isolated, our intention here is not to treat them as victims only, but in a proactive manner as well. They are 
all unique individuals, with certain action potential, who can be brought back (again) into society and everyday lives through a synergy of social support and cohesion. At least this seems to be plausible when it comes to demographically vital portions of homeless, younger and middle-aged, men and women, especially those with some human and cultural capital.

\section{Data and Method}

The last Census of Population, Households and Dwellings in the Republic of Serbia carried out in 2011, gathered together and presented, for the first time, the data on the so-called primary homeless.

The primary homeless in the 2011 Census is defined as individuals without permanent or temporary homes, living in streets, parks, under bridges, etc. The collection of data on them was done during the pre-enumeration phase (from 1 to 30 September 2011) in collaboration with the Republic Institute for Social Protection, Province Institute for Social Protection and non-governmental organizations. Any person who searched for placement or some other type of service at the relevant social protection institutions during September 2011 was included. Therefore, the primary homeless were enumerated solely through social institutions and not at the place where they usually resided (in the streets, parks, etc.). Furthermore, the enumerators had to distinguish in between primary homeless from other persons who, for example, had come to reception centers, drop-in centers and homeless shelters, only for a brief care, intake of food and clothes, and then returned to their own households (SORS, 2011). As a result, the volume of registered primary homeless was probably underestimated, due to the very method of (indirect) data collection and weather conditions of belated summer. The primary homeless are exceptionally active, they are predominantly male, urban population, who frequently develop solid coping strategies, use own social networks within their marginalized group, which altogether might have added to their lower visibility at the time (compare: Žarković, Petrović and Timotijević, 2012).

Other than primary homeless, the Statistical Office of the Republic of Serbia also collected census data on secondary homeless, from 1 to 15 October 2011, like in previous enumeration rounds. These are defined as: people living in facilities occupied out of necessity, such as: sheds, barracks, trailers, wagons, cellars, tents, barges, cardboard and informal settlements (SORS, 2013) ${ }^{4}$.

In this paper we applied statistical and sociodemographic methods, with the complementary use of secondary analysis of other researches, analytical and synthetic methods.

\section{Discussion}

In the following chapters we will depict some basic sociodemographic characteristics of homeless in Serbia. Due to the lack of space, secondary homeless will be in our focus, while primary will be given only in few detail. The reasons are twofold: former are more

${ }^{4}$ The differentiation among primary and secondary homeless in the 2011 Census has been adopted following international recommendations so that each country defines these categories and accepts the obligation to enumerate both sub-groups. 
numerous and since they have also been registered in the previous census, in 2002, some comparative perspective will be drawn upon.

In 2011, there were 445 primary homeless registered, almost all of them in urban and only three in other (rural) ${ }^{5}$ settlements. Majority have been residing in the capital, in the region of Belgrade (164), followed by Vojvodina (160). Quite obviously, it is cities where most of homeless move in to find shelter and socialprotection and occasional work, as well.

Secondary homeless are, however, more numerous ${ }^{6}$. The 2011 Census registered 17,842 ( $0,3 \%$ of the total population), three times larger compered to EU. Most of them come from urban settlements (63.1\%). Again, vast majority were found in the City of Belgrade $-39.0 \%$, then in the Region of Šmadija and West of Srbija (25.5\%), with the smallest portion to be registered in the poorest territory, of the south and east (21.8\%) of the country. This might sound paradoxical, but the fact is that homeless strive to reach urban centers where they can find some work and social protection.

In between two census rounds the volume of secondary homeless has been decreasing (in 2002 there were 21,636 registered, meaning $17.54 \%$ more than in 2011). This might be interpreted through depopulation, especially high emigration to the EU, owing to free visa regime, just as in the case of the general population. The secondary homeless are most numerous in the following Belgrade municipalities: Novi Beograd (1575), Palilula (1025), Čukarica (754) and Zemun (607). These 4 altogether total for 3961, i.e., $1 / 5(22.2 \%)$. In the rest of the country, the cities with a larger number of the secondary homeless are: Kragujevac (493), Kraljevo (413) and Kruševac (395). In the City of Niš there is a total of 699 secondary homeless recorded (3.9\%), while even fewer (521) of them were recorded in the City of Novi Sad. Cities offer greater opportunities in finding some paid work and are the centers of social protection. From this point on, we will restrict our interpretation to secondary homeless.

\section{Age and gender}

The above age and gender distribution or a popular 'pyramid' reflects the most basic demographic structure, which molds all relevant sociodemographic features of the observed population. In the case of homeless it is a 'stationary type' pyramid, with broader basis, which is narrowing to the top (Figure 1), unlike 'regressive' one in the total population of Serbia, which is less favorable because of the shrinking at the bottom and extending at the top as a result of long lasting low fertility and low mortality (advanced ageing and depopulation) (Penev, 2015).

When speaking of homeless, the youngest generations are most numerous, i.e. every fourth person is $0-14$ of age (23\%). One out of five is $45-59(21 \%)$, while one in ten is over 70 (11.3\%). If compared to the total population of Serbia, homeless have somewhat better age composition, most probably due to higher fertility and traditional family model. The

\footnotetext{
${ }^{5}$ Other settlements encompass both rural and 'mixed' type ones, i.e. all those that are neither genuine rural nor urban ones.

${ }^{6}$ According to FEANTSA estimates, there is around 410,000 homeless in the EU at any given night ( $0.08 \%$ of the total population of EU $-512,700,000$ ), (EPRS, 2019) which amounts to around 4.1 million homeless during the whole year for shorter or longer period (https://www.feantsa.org/en/ about-us/faq).
} 
share of youth is thinner in the total population (14.3\%), with middle aged and elderly being more voluminous $(45-59,22.3 \%$ and $70+, 12.7 \%)$. As to gender composition, males are slightly more numerous (8995 males and 8847 females), with the increasing share of women along the older ages (age $70+, 14.6 \%$ women versus $8 \%$ of men). Similar trends are registered among the total population $(14.6 \%$ women in ages $70+$, with even higher share of males in $70+, 10.6 \%)$. This means higher mortality and shorter life span reflected in fewer males among the elderly homeless relative to the total population.

\section{Marriage, Family and Households}

Never married are most numerous which is in line with the relatively younger age composition (Figure 2. The difference is obvious when it comes to gender, with more than half of men being unmarried (51\%) compared to the one third of women (32\%). The share of married men and women is balanced. Among the total population of Serbia, the share of both unmarried men and women is lower $(33.4 \%$ and $23.0 \%$ respectively) (Stanković, 2015). This difference reflects the lower social position/marginalization and thus less favorable marriage market for the homeless.

Majority live in one person households (46.4\%), which is related to being single, without a partner and family and also ageing, thus evident social marginalization (Bobić, 2014). They are followed by two-member households (21\%). Among the rest, the most numerous are those with three members (11.1\%), followed by those with four $(9.6 \%)$. One out of four households embraces nuclear family (a couple with children),(23.4\%), while one out or eight is single parent (12.7\%, with prevalence of singlemothers, $10.2 \%)$ with almost the same number of nuclear family households (12.5\%), (Bobić, 2014).

\section{Education}

Very low education is dominant among homeless within both males and females Figure 3 surmounting to as many as half with only primary education or less Figure 3 . Every fifth woman does not possess any formal education whatsoever, while one out of three men have a secondary school degree. As to the population of Serbia, secondary education prevails, both among men (54.3\%) and women (43.9\%), (Šobot, 2015). Lower (elementary and less) education is registered with $29.1 \%$ men and $39.4 \%$. When compared to age and gender composition, these findings demonstrate a poor human capital of the homeless and therefore stronger social exclusion which is also reflected in economic features.

\section{Economic Features}

In line with the above, inactive persons (68.4\%) are dominant (Bobić, 2014).One in three is economically active (31.6\%). There is a high share of children and young who allegedly attend schools (26.8\%) and every seventh one is a retired (15.1\%).

Simple occupations in the primary and secondary sector are most widespread at the very bottom of the social hierarchy, with low income, uncertain and unstable pays, meaning that these people are vastly precarious, and thus genuine 'losers' of social transformation. One in three belongs to elementary occupations (Figure 4) (30.9\%), with almost lack of gender-related differences. With men, the second most prevalent is: craft and related trade workers (19.7\%), followed by equal portion of both service and sales workers (12\%) and machine operators and assemblers (12\%) and finally, skilled agricultural, forestry and fishery workers (10.7\%). Women are also predominant among simple jobs (29.8\%), then 
trade and service ones (22.8\%). However, according to the last census, the third place is taken by women whose occupations fall under middle strata, with the share being as much as three times bigger compared to men (technicians and associate professionals, $14.8 \%$ compared to $5.5 \%$ men)

In the total population of Serbia, in 2011, comparably better educated, engineers, professional associates and technicians are most dominant (16.2\%), followed by service and sales workers (16.1\%), (Radivojević, 2015). The third place was occupied by professionals and artists, all of three groups adding to the high share of middle social strata of employed with stable and better paid jobs, so called transition winners. Elementary occupations are registered in as few as 7.9\%. These findings show the full scale of vulnerability of homeless whose cultural, economic and social capitals are scarce and therefore pull them to the very edge of social hierarchy.

\section{Ethnicity and Migration}

Majority homeless declared themselves as Serbs in the last census (58\%), which is much fewer compared to the total population, (83.3\%) while $1 / 3$ said to be Roma (32\%). When compared to the total population, the over representation of Roma is evident $(2,1 \%$ in the total population), (SORS, 2013). When it comes to migration history, homeless predominantly move within Serbia, from one municipality to another (to Belgrade and other cities), (65.5\%), while $17.6 \%$ arrived from ex-Yugoslav republics, data also approved in the empirical studies (Žarković, Petrović and Timotijević, 2012). As to internally displaced, at the time of census, it was estimated that 3,358 resided in 54 collective centers, which might be the proxy for the volume of homeless among them (http://www.kirs.gov.rs/wb-page. php?kat_id $=34)^{7}$. Among those being returned from the EU on the basis of readmission agreement (2.1\%), Roma are predominant.

\section{Conclusion: Towards Intervention}

Upper findings demonstrate that on average (secondary) homeless is a male, middle aged, 20-64 (55.9\%), living in urban settlements, under extremely precarious housing and material conditions, with primary education or less, performing elementary jobs, unmarried, without family, with every third declaring as Roma. On the basis of presented discussion we can assume that homelessness is evidently socially constructed phenomenon. The way how one group or a society as a whole treat these people primarily shapes policies aimed at control and prevention, allocation of funds, methods and measures for assistance, social integration, etc. (Jovičić, 2010). The homelessness is not a static, but rather dynamic phenomenon, with different probabilities of entering into and exiting out, including also the length of being in this status. The destiny of homeless crucially depends on the country of residence, social biography, event in one's life course and coping strategies to be enacted.

Among the contemporary scholars, there is a predominant viewpoint that these people need to be understood and empowered, but also supported to be brought back into community (Jugović \& Luković, 2012). The researches show that although there

\footnotetext{
${ }^{7}$ Relevant study (Nikitović, 2015) claims approximately 100,000 of IDPs to have been registered in the last census, meaning that some $3.4 \%$ were secondary homeless among them.
} 
are different ways how legal, political, national authorities and local citizens treat them, they all have something in common, irrespective of the country they live in the harsh experience of everyday living, so that their every day life is vastly devastated and brought down to mere striving for basic needs (hygiene, shelter, food, clothing, footwear, etc.), with only few trying to a find a way out (Jovičić, 2010, 36). Contemporary European societies advocate for a proactive attitude, i.e., reintegration of these people from the streets, thus conversion from victimhood into agency, without fast elimination of necessary and continuous social assistance from local communities, families, neighborhoods. Consequently, the main direction of political and civil action should be aimed at reducing their dependence on social protection, i.e., on the state and services, along with the instigation of relying on individual resources and encouraging them to re-establish old ones and build up new social networks (Jovičić, 2010; Timotijević, 2012). 
Мирјана В. Бобић ${ }^{1}$,

Универзитет у Београду,

Филозофски факултет, Одељење за социологију

Београд (Србија)

\title{
СОЦИОДЕМОГРАФСКИ ПРОФИЛ БЕСКУЋНИКА У СРБИЈИ²
}

\author{
(Превоg In Extenso)
}

Сажетак: Ово је један од ретких радова о бескућницима у Србији чији је циљ да представи њихов социодемографски профил. Главни извор података је попис становништва, а основна метода је статистичка. Поред тога, применили смо секундарну анализу неколико квалитативних истраживања, чији су налази коришћени комплементарно. У раду је приказано да велику већину бескућника чине мушкарци, млађих и средњих година, неожењени, са ниским образовањем, који обављају једноставна занимања. Многи од њих су Роми, имигранти из региона и повратници из ЕУ. Тумачење налаза, коме претходи кратки преглед друштвеног контекста ове појаве у Србији, а делом и у ЕУ, довело је до закључака који су резимирали профил бескућника и указали на интервенцију која има за циљ да их извуче са социјалне маргине, али и да спречи улазак многих особа у ризик бескућништва.

Кључне речи: бескућници, Србија, социодемографски профил, социјална конструкција феномена, социјална искљученост.

\section{Увод: Основни појмови и циљеви}

Бескућништво је веома сложен проблем екстремне друштвене депривације (Bobić, 2014). Као прво и најважније, уско је повезано са недостатком смештаја или неадекватним условима становања, а затим и са укупним сиромаштвом као двема основним димензијама социјалне искључености. Бескућницима недостају хумани ресурси: приходи, запослење, имовина, уштеђевина, скуп вештина, образовање, културни капитал и углед у друштву (Jugović, Luković, 2012). Бескућници не поседују социјални капитал будући да их обично напуштају супружници и породица, рођаци, комшије, пријатељи, колеге, чланови локалних заједница, етничких група итд. Недостају им стратегије преживљавања и начини превазилажења вишеструких изазова живота у ризичном друштву. Бескућништво је, дакле, пасиван одговор и неприлагођеност на мешавину неповољних догађаја и животног тока и последица погрешних личних избора.

\footnotetext{
1 mirjana.bobic@gmail.com

2 Рад је резултат рада ауторке на пројекту „Изазови нове друштвене интеграције у Србији: концепти и актери" који од 2011. године спроводи Институт за социолошка истраживања Филозофског факултета и финансира Министарство просвете, науке и технолошког развоја Републике Србије (бр. 179035).
} 
Бескућници се суочавају са круцијалним животним прекретницама које доводе до тога да они буду без крова, без посла, лошег здравља и сами. Бескућништво је често резултат недостатка социјалне државе и социјалне заштите, посебно у јужној Европи, али и у земљама постсоцијалистичке трансформације, за разлику од скандинавских држава чија је политика великодушнија. Пад подршке од стране породице данас је последица друге демографске транзиције, укратко, промењеног става према браку и породици и мање склоности да се формира заједница (Bobić \& Vukelić, 2011). Све учесталији распад породица води ка порасту броја/удела самаца, разведених, удовица, једнородитељских породица, старих домаћинстава итд. Са друге стране, често се читаве породице гурају на социјалну маргину, због оружаних сукоба и миграција, као што је био случај са бившим југословенским републикама 1990-их, са избеглицама, интерно расељеним лицима (која су у централну Србију и Војводину стигле са Косова и Метохије 2000--их), итд.

Ризици од бескућништва су многобројни: (дугорочна) незапосленост, недостатак прихода и ресурса, лоше образовање и с тим повезане потешкоће у приступу радној снази. У ЕУ бескућници се такође регрутују из редова особа без докумената или са нерешеним питањем националне припадности или статуса држављанства (имигранти, азиланти, илегални странци, особе без боравишних исправа) (Avramov, 2006).

Бескућницима се означавају људи који су или смештени или користе услуге склоништа за бескућнике, прихватних објеката, сигурних кућа итд. Такође, у ЕУ као и у Србији, број бескућника је у сталном порасту због растуће популације старих у развијеним друштвима. Већина их долази из колективних центара, казнених установа, психијатријских болница, стационара, затвора итд. Често се отпуштају без места на које би отишли, јер их породице и рођаци обично одбацују, те су због тога присиљени да се стално селе у зачараном кругу, од болнице/затвора до прихватилишта и натраг, у условима пада јавне социјалне заштите, финансијских ограничења, реформи социјалне заштите, недостатка партнерства између јавних и приватних актера у овом домену итд. (Žarković, Petrović \& Timotijević, 2012; Ljubičić, 2013, 2018).

У социологији постоји израз „поткласа” који обухвата и бескућнике и створен је у англосаксонској литератури (енг. underclass). То је хетерогена група која настаје као резултат просторне и индустријске реконструкције капитализма, нових процеса урбанизације и реорганизације простора, који често доводе до расељавања читавих група или популација, а неретко стварајући „сиромаштво гета” (Wilson, 1989, according to: Tomanović, S. et al., 2014).

Да би се превазишле бројне и значајне разлике у концептуализацији и интерпретацији феномена, које одражавају различиту друштвену и просторну развијеност држава благостања и мера социјалне заштите у европским државама и регионима, законски третман, социјална права, мере подршке, ставове јавности, Европска федерација националних организација које раде са бескућницима (енг. European Federation of National Organisations Working with the Homeless - FEANTSA) ${ }^{3}$ основала је Европску опсерваторију 1991. године. Њена сврха била је да олакша прикупљање података и ширење знања о бескућницима у државама чланицама ЕУ. Осмишљена

\footnotetext{
${ }^{3}$ FEANTSA, основана 1989. године, је једина европска невладина организација која се искључиво фокусира на бескућништво. Окупља преко 130 организација чланица из 30 земаља, укључујући 28 држава чланица ЕУ.
} 
је јединствена типологија бескућништва и социјалне искључености - Европска типологија бескућништва (енг. European Typology of Homelessness - ETHOS, www. feantsa.org). Осим стамбене димензије као најосновније личне потребе, ова типологија посматра бескућнике као вишедимензионални феномен (Avramov, 1995, 1996, 1999, 2002; Jovičić, 2011; Žarković, Petrović \& Timotijević, 2012; Jugović \& Luković, 2012):

- без крова над главом (без икаквог заклона, ноћење у тешким условима);

- без куће (са смештајем, али привременог карактера у установама или прихватилиштима);

- несигурно становање (под претњом озбиљне искључености због несигурног закупа, исељења, породичног насиља);

- неадекватно становање (у камп приколицама, у илегалним камповима, у неподобним стамбеним јединицама, са превише људи).

Наведени критеријуми означавају „кровни концепт” који заправо покрива различите групе људи које нису у стању да обезбеде приватно, трајно и квалитетно становање захваљујући личним ресурсима, како због финансијских тако и због других социјалних баријера. Истина је да ти људи нису у стању да живе пристојно и независно и зато им је потребна стална нега и помоћ, али обично не институционализација (упореди: Avramov, 1995, 72, Avramov,1996).

У Србији је бескућништво и даље маргинализовано, без јасних стандарда који би недвосмислено дефинисали минималне услове становања. Зато се примењују само релативно широка и недовољно дискриминаторна поимања „примарног” и „секундарног” бескућника (Žarković, Petrović \& Timotijević, 2012). У стварности, у Србији постоје најмање три врло широке и хетерогене групе, које представљају или праве бескућнике у складу са поменутом концепцијом ЕУ, или људе који су под великим ризиком:

- сиромашне и бројне групе домаћинстава и људи без приступа тржишту станова, посебно социјалног становања, широке категорије такозваних социјално угрожених група;

- врло хетерогено усељеничко становништво од почетка деведесетих до данас (војни бескућници, породице војних лица из бивших југословенских република, удовице и деца убијених/несталих војника из ратова у бившој Југославији 1990-их), избеглице (из Хрватске, Босне и Херцеговине), интерно расељено становништво (са Косова и Метохије) и повратници који долазе из ЕУ према Споразуму о реадмисији;

- ромска етничка група.

Обим и разноликост бескућника у Србији нису занемарљиви. Управо супротно, ако ригорозно применимо поменуту типологију (ETHOS), скоро 10\% укупног становништва земље чинили би бескућници или људи који су под сталним ризиком од бескућништва (око 800-900.000, упореди: Žarković, Petrović \& Timotijević, 2012, str. 14).

Нажалост, Србији недостаје стратешки, сложен, систематски и координисани план акције против бескућништва, који би се такође бавио превенцијом код категорија људи у ризику.

Основни циљ овог рада је приказивање бескућништва у Србији. Због недостатка простора биће представљени само просечни социо-демографски подаци, док се детаљније информације могу наћи у неким другим делима аутора (Bobić, 2014).

Рад је структуриран тако да након уводног поглавља разрађујемо социјални контекст, након чега следи објашњење података и метода. Четврто поглавље доноси 
дискусију о главним резултатима, а последње доноси закључке давањем неких практично политичких препорука.

\section{Друштвени контекст}

Пост-транзициона Србија је класификована као европска полу-периферија, безнадежно покушавајући да ухвати корак са земљама центра ЕУ као и остатком глобализованог, развијеног света, што је циљ који ће тешко икада бити достигнут (Blagojević Hughson, 2013). Укључивање у неолиберални светски систем снажно је контролисан од стране међународних финансијских институција (ММФ, Светска банка) применом стриктних принципа, као што су: приватизација, либерализација трговине, промоција директних страних инвестиција, фискална дисциплина, пореске реформе, повећана ефикасност јавних трошкова, финансијска либерализација, економска дерегулација, флексибилизација рада, итд. То је такозвана „нормализација” и „економска и политичка стабилизација” које су уследиле после 2000. (Lazić, 2011) и довеле до високе незапослености и пораста сиромаштва код велике већине грађана у Србији, од којих су многи раније били запослени у јавном сектору (јавна управа, образовање, здравство, социјална заштита, итд.). Неки стручњаци ово називају „раз-развојем”, изразом који је позајмљен од економиста за описивање експлоатације и девастације људског капитала, институција и инфраструктуре у земљама које пролазе кроз транзицију (Blagojević, 2013, str. 44). Ово је уско повезано са свеукупним друштвеним „раз-развојем” на полу-периферији (Blagojević, 2013, str. 44), што се најбоље може описати димензијама као што су: деиндустријализација, повећано сиромаштво и социјална неједнакост, интензивна неформализација економије, пад социјалне заштите и пораст социјалне угрожености, депопулација, узрокована ниском плодношћу и великом емиграцијом, а све то је у тесној вези са погоршањем квалитета живота, великим утицајем економије преживљавања, сталном производњом „вишкова” становништва, због дугорочне, високе незапослености, недовољне запослености, флексибилног радног ангажмана, смањења броја радника и отпуштања итд.

Као и у другим земљама које се трансформишу, и у Србији бескућништво није нова појава. Наиме, оно је већ било познато у социјализму. Ипак, бескућништво је тада било сакривено водећом комунистичком идеологијом, која је наглашавала социјалну правду и солидарност. С друге стране, бескућништво је такође било мање видљиво због недостатка стамбеног простора за све, као резултат убрзане индустријализације после Другог светског рата и споре урбанизације. То је допринело ширењу „мешовитих домаћинстава” људи који живе на селу и раде у привреди у оближњим градовима, од којих су многи прибегли изградњи илегалних приградских насеља, док су други наставили да живе у стамбеним јединицама са више породица под једним кровом у градовима итд. (уп. Timotijević, 2012, str. 42; Petrović, 2004; Milić et al., 1981). Пост-социјалистичком периоду додато је „ново” или бескућништво повезано са транзицијом (Timotijević, 2012), иницирано: трансформацијом и приватизацијом становања, опадањем станоградње, редуковањем и нестанком система социјалног становања, наслеђеним из социјализма, порастом цена станова у градовима и успостављањем високих тржишних цена станова, увођењем хипотека и заплене станова на рачун неизмирених, неплаћених банкарских кредита и огром- 
них трошкова становања. Све ове недостатке допуњују и/или погоршавају висока и хронична незапосленост, чести губици посла и имовине, повећана нестабилност породице, породично насиље, алкохолизам, злоупотреба дрога, итд. (Žarković, Petrović and Timotijević, 2012; Timotijević, 2012; Petrović, 2004, 2009).

Ипак, иако су бескућници очигледно изузетно девастирани и изоловани, наша намера овде није да се они третирају само као жртве, већ и на проактиван начин. Сви они су јединствени појединци, са одређеним акционим потенцијалом, који се могу (поново) вратити у друштво и свакодневни живот кроз синергију социјалне подршке и кохезије. Ово се барем чини могућим када је реч о демографски виталном делу бескућника, млађих и средњих година, мушкарцима и женама, посебно оним са неким хуманим и културним капиталом.

\section{Подаци и метод}

Последњи Попис становништва, домаћинстава и станова у Републици Србији спроведен 2011. године сакупио је и по први пут објавио податке о такозваним примарним бескућницима.

Примарни бескућници у Попису из 2011. године дефинисани су као појединци без сталних или привремених домова, који живе на улицама, парковима, испод мостова, итд. Прикупљање података о њима обављено је у фази предпописивања (од 1. до 30. септембра 2011.) у сарадњи са Републичким заводом за социјалну заштиту, Покрајинским заводом за социјалну заштиту и невладиним организацијама. Укључена је свака особа која је током септембра 2011. године тражила смештај или неку другу врсту услуге у одговарајућим установама социјалне заштите. Стога су примарни бескућници пописани искључиво кроз социјалне установе, а не на месту где су обично боравили (на улицама, парковима итд.). Поред тога, пописивачи су морали да разликују примарне бескућнике од других особа које су, на пример, дошле у прихватне центре, свратишта и прихватилишта само ради краткотрајног збрињавања, преузимања хране и одеће, а затим се вратиле у своја сопствена домаћинства (SORS, 2011). Као резултат, број регистрованих примарних бескућника вероватно је потцењен, због саме методе (индиректног) прикупљања података и временских услова михољског лета. Примарни бескућници су изузетно активни, то је претежно мушко, урбано становништво, које често развија солидне стратегије сналажења, користи сопствене друштвене мреже у оквиру своје маргинализоване групе, што је у целини могло да допринесе њиховој слабијој видљивости (упореди и: Žarković, Petrović and Timotijević, 2012).

Поред примарних бескућника, Републички завод за статистику такође је прикупљао податке о секундарним бескућницима од 1. до 15. октобра 2011. године, као и код претходних пописа. Они су дефинисани као: лица који живе у објектима настањеним из нужде, као што су: шупе, бараке, приколице, вагони, подруми, шатори, барже, картонска и неформална насеља (SORS, 2013) ${ }^{4}$.

\footnotetext{
${ }^{4}$ Разликовање између примарних и секундарних бескућника током Пописа 2011. године усвојено је на основу међународних препорука тако да свака држава дефинише ове категорије и прихвата обавезу пописа обе подгрупе.
} 
У овом раду смо применили статистичке и социодемографске методе, уз комплементарну употребу секундарних анализа других истраживања, затим и аналитичке и синтетичке методе

\section{Дискусија}

У наредним поглављима ћемо приказати неке основне социодемографске карактеристике бескућника у Србији. Због недостатка простора, у фокусу ће нам бити секундарни бескућници, док ће се о примарним говорити само у неколико детаља. Разлози су двоструки: прва група је бројнија и будући да су регистровани и у претходном попису становништва, 2002. године, могуће је доћи до неке упоредне перспективе.

Пописом 2011. године регистровано је 445 примарних бескућника, готово сви у урбаним, а само три у другим (руралним $)^{5}$ насељима. Већина живи у главном граду, у региону Београда (164), следи Војводина (160). Сасвим је очигледно да су то градови у које већина бескућника дође како би пронашла уточиште и социјалну заштиту, а такође и повремени посао.

Међутим, секундарни бескућници су бројнији ${ }^{6}$. Пописом становништва 2011. године регистровано је 17.842 оваквих бескућника (0,3\% укупног становништва), три пута више у односу на ЕУ. Већина њих долази из градских насеља $(63,1 \%)$. Поново, велика већина је пронађена у граду Београду - 39,0\%, затим у региону Шумадије и Западне Србије (25,5\%), а најмањи део је регистрован на најсиромашнијој територији југа и истока $(21,8 \%)$ земље. То можда звучи парадоксално, али чињеница је да бескућници теже томе да дођу у урбане центре где могу да пронађу посао и социјалну заштиту.

Између два круга пописа, број секундарних бескућника се смањује (2002. године било их је 21.636, што је за 17,54\% више него 2011.). То се може тумачити депопулацијом, посебно великом емиграцијом у ЕУ, захваљујући слободном визном режиму, баш као што је случај са општом популацијом. Секундарни бескућници најбројнији су у следећим београдским општинама: Нови Београд (1575), Палилула (1025), Чукарица (754) и Земун (607). Ове 4 општине дају збир од 3.961, тј. 1/5 (22,2\%). У остатку земље, градови са већим бројем секундарних бескућника су: Крагујевац (493), Краљево (413) и Крушевац (395). У Нишу је забележено укупно 699 секундарних бескућника (3,9\%), док је још мањи број (521) евидентиран у Новом Саду. Градови нуде веће могућности за проналажење неког плаћеног посла и центри су социјалне заштите. Од овог тренутка ограничићемо наше тумачење на секундарне бескућнике.

\section{Старост и пол}

Приказана дистрибуција старости и пола или популарна „пирамида” одражава најосновнију демографску структуру, која обликује све релевантне социодемографске карактеристике посматране популације. Код бескућника се ради о пирамиди „ста-

\footnotetext{
${ }^{5}$ Остала насеља обухватају рурална и насеља мешовитог типа, тј. сва она која нису ни права рурална, ни урбана насеља.

6 Према проценама федерације FEANTSA, било које ноћи у ЕУ се налази око 410.000 бескућника (0,08\% укупног становништва ЕУ - 512.700.000) (EPRS, 2019.), што износи око 4,1 милиона бескућника током целе године на краћи или дуживременски период (https:// www.feantsa.org/en/about-us/faq).
} 
ционарног типа", са широм основом, која се сужава ка врху (Графикон 1], за разлику од „регресивне” код укупног становништва Србије, која је неповољнија због сужења при дну и ширења ка врху које је резултат дуготрајне ниске плодности и ниског морталитета (убрзано старење и депопулација), (Penev, 2015).

Када говоримо о бескућницима, најмлађе генерације су најбројније, тј. свака четврта особа је старости 0-14 година (23\%). Једна од пет је старости 45-59 година (21\%), док је свака десета особа старија од 70 година (11,3\%). Ако ово упоредимо са укупним становништвом Србије, бескућници имају нешто бољу старосну структуру, највероватније због веће плодности и традиционалног породичног модела. Учешће младих је мање у укупном становништву (14,3\%), а особе средњих година и старији су бројнији (45-59, 22,3\% и 70+, 12,7\%). Када је реч о полном саставу, мушкарци су нешто бројнији (8.995 мушкараца и 8.847 жена), са све већим уделом жена старије доби (70+ година, $14,6 \%$ жена у односу на $8 \%$ мушкараца). Слични трендови регистровани су међу укупном популацијом (14,6\% жена доби $70+$, са још већим уделом мушкараца доби $70+, 10,6 \%)$. То значи већи морталитет и краћи животни век који се одражава на мањи број мушкараца међу старијим бескућницима у односу на целокупну популацију.

Брак, породица и домаћинство

Особе које никада нису биле у браку су најбројније, што је у складу са релативно млађим старосним саставом (Графикон 2). Разлика је очигледна када је реч о полу, при чему је више од половине мушкараца неожењено (51\%) у порећењу с трећином жена (32\%). Удео ожењених мушкараца и жена је уравнотежен. Међу укупним становништвом Србије, удео неожењених мушкараца и неуданих жена је мањи (33.4\% и 23.0\% респективно), (Stanković, 2015). Ова разлика одражава нижи социјални положај/ маргинализацију, а самим тим неповољније „брачно тржиште” за бескућнике.

Већина живи у једночланим домаћинствима (46,4\%), што је повезано са статусом самца, без партнера и породице, а такође и са старењем, па тако и евидентном друштвеном маргинализацијом (Bobić, 2014). Након њих следе двочлана домаћинства $(21 \%)$, затим трочлана $(11,1 \%)$ и четворочлана домаћинства $(9,6 \%)$. Једно од четири домаћинства обухвата нуклеарну породицу (пар са децом), (23,4\%), док је једна од осам особа самохрани родитељ (12,7\%, са преваленцијом самохраних мајки, 10,2\%), и готово истим бројем домаћинстава нуклеарне породице (12,5\%) (Bobić, 2014).

\section{Образовање}

Врло ниско образовање је доминантно међу бескућницима и код мушкараца и код жена Графикон 3, где је чак половина ове популције са само основним образовањем или нижим (Графикон 3). Свака пета жена нема никакво формално образовање, док један од три мушкарца има средњу школу. Што се тиче укупног становништва Србије, превладава средњошколско образовање, како међу мушкарцима (54,3\%), тако и међу женама (43,9\%), (Šobot, 2015). Ниже (завршено и незавршено основно) образовање регистровано је код 29,1\% мушкараца и $39,4 \%$ жена. У поређењу са старосним и полним саставом, ови налази показују низак хумани капитал бескућника и самим тим јачу социјалну искљученост која се такође огледа у економским карактеристикама. 


\section{Економске одлике}

У складу с горе наведеним, неактивна лица (68,4\%) су доминантна (Bobić, 2014). Свако треће лице је економски активно (31,6\%). Велики је удео деце и младих наводно на школовању (26,8\%), а свако седмо лице је пензионер (15,1\%).

Једноставна занимања у примарном и секундарном сектору најраспрострањенија су на самом дну друштвене хијерархије, са малим примањима, несигурним и нестабилним платама, што значи да се ти људи осећају несигурно и стога су прави губитници друштвене трансформације. Свако треће лице се бави једноставним занимањем (Графикон 4), (30,9\%), а готово да нема разлике међу половима. Код мушкараца, други по заступљености су занатлије и сродни радници (19,7\%), затим следи једнаки удео запослених у трговини и услугама (12\%), руковаоци машинама и монтери (12\%) и коначно, квалификовани пољопривредници, шумари, рибари (10,7\%). Код жена такође преовлађују једноставна занимања $(29,8 \%)$, затим услужна и трговачка занимања $(22,8 \%)$. Међутим, према последњем попису становништва, треће место заузимају жене чија занимања спадају у средње слојеве, а удео је чак три пута већи у односу на онај код мушкараца (техничари и стручни сарадници, 14,8\% у поређењу са 5,5\% код мушкараца).

У укупном становништву Србије, 2011. године, доминирају упоредно боље образовани, инжењери, стручни сарадници и техничари (16,2\%), а следе услужна и трговачка занимања (16,1\%), (Radivojević, 2015). Треће место заузели су стручњаци и уметници, а све три групе допринеле су високом уделу средњег слоја који чине запослени са стабилним и боље плаћеним пословима, такозвани добитници транзиције. Једноставна занимања су регистрована код свега 7,9\% особа. Ови налази показују потпуну рањивост бескућника чији су културни, економски и социјални капитал оскудни што их повлачи на сам руб друштвене хијерархије.

\section{Етницитет и миграције}

Већина бескућника се изјаснила као Срби на последњем Попису становништва (58\%), што је знатно мање у поређењу са укупним становништвом (83,3\%), док је $1 / 3$ рекло да су Роми (32\%). У поређењу са укупним становништвом, евидентна је велика заступљеност Рома (2,1\% у укупном становништву) (SORS, 2013). Када је реч о миграционом пореклу, бескућници се углавном селе унутар Србије, из једне општине у другу (у Београд и друге градове), (65,5\%), док је 17,6\% стигло из бивших југословенских република, што су подаци који су такође потврђени емпиријским студијама (Žarković, Petrović and Timotijević, 2012). Што се тиче интерно расељених, током пописа становништва процењено је да је у 54 центра за колективни смештај боравило 3.358 особа, што се може узети као представа о броју бескућника међу њима (http://www.kirs.gov.rs/wb-page.php?kat_id=34). ${ }^{7}$ Међу онима који су враћени из ЕУ на основу споразума о реадмисији $(2,1 \%)$, преовлађују Роми.

\footnotetext{
7 Релевантна студија (Nikitović, 2015) тврди да је око 100.000 интерно расељених лица регистровано на последњем попису становништва, што значи да је међу њима било око $3,4 \%$ секундарних бескућника.
} 


\section{Закључак: ка интервенцији}

Горњи налази показују да је (секундарни) бескућник у просеку мушкарац, средњих година, 20-64 (55,9\%), који живи у урбаном насељу, под изузетно несигурним стамбеним и материјалним условима, са основним или непотпуним основним образовањем, који обавља једноставно занимање, неожењен, без породице, а сваки трећи се изјашњава као Ром. На основу изнесене расправе можемо претпоставити да је бескућништво очигледно друштвено конструисан феномен. Начин на који једна група или друштво у целини третира ове људе првенствено обликује политику усмерену ка контроли и превенцији, расподели средстава, метода и мера за пружање помоћи, социјалну интеграцију итд. (Jovičić, 2010). Бескућништво није статичан, већ прилично динамичан феномен, са различитим вероватноћама уласка и изласка, укључујући и дужину боравка у таквој ситуацији. Судбина бескућника пресудно зависи од земље пребивалишта, друштвене биографије, догађаја у нечијем животном току и стратегијама сналажења.

Међу савременим научницима постоји преовлађујуће гледиште да је те људе потребно разумети и оснажити, али и подржати да би се поново вратили у заједницу (Jugović \& Luković, 2012). Истраживања показују да, иако су начини поступања законодавних, политичких, националних власти и локалних грађана према њима различити, сви деле нешто заједничко, без обзира на земљу у којој живе - тешко искуство свакодневног живота, тако да је њихова свакодневница увелико осиромашена и сведена на пуку тежњу ка задовољењу основних потреба (хигијена, склониште, храна, одећа, обућа итд.), док је само неколицина покушала да пронађе излаз (Jovičić, 2010, str. 36). Савремена европска друштва залажу се за проактиван став, тј. реинтеграцију ових људи са улица, те претварање жртве у актера, без брзог укидања неопходне и континуиране социјалне помоћи локалних заједница, породица, суседа. Сходно томе, главни смер политичког и грађанског деловања требао би да буде усмерен на смањење њихове зависности од социјалне заштите, тј. од државе и служби, заједно с подстицањем ослањања на појединачне ресурсе и на поновно успостављање старих и изградњу нових друштвених мрежа (Jovičić, 2010; Timotijević, 2012).

\section{REFERENCES/ ЛИТЕРATУРА}

Avramov, D. (2006) Outstanding issues in research of social inclusion and evaluation of performance, paper presented at European Science Foundation (ESF) SCSSS Exploratory Workshop, York, 26-28 March.

Avramov, D. (2002) People, Demography and Social Exclusion. Strasbourg: Council of Europe Publishing.

Avramov, D., et al, (1999). Coping with Homelessness. Issues to be tackled and Best Practices in Europe. Ashgate Pub, Ltd.

Avramov,D. (1996).The Invisible Hand of th eHousing Market: A Study of the Effects of Changes in the Housing Market and Homelessness in the European Union. Brussels:FEANTSA 
Avramov, D. (1995).Homelessness in the European Union. Social and Legal Context of Housing Exclusion in the 1990s. Brussels: FEANTSA.

Blagojević, M. (2013). Gender Barometer in Serbia: Development and Everyday Life. Beograd: UN Women [In Serbian]

Bobić, M. (2014). Homeless.Beograd: RZS[In Serbian]

Bobić, M. \& Vukelić, J. (2011). Second Demographic Transition De-Blocked?, Sociologija, 53 (2), 149-176. DOI: 10.2298/SOC1102149B In Serbian],

EPRC (2019). Demographic Outlook for the European Union 2019. European Parliamentary Research Service, Brussels: European Union.

Jugović, A. \& Luković, M. (2012). Phenomenology of homelessness in the contemporary society, Socijalna misao, 4, 11-28. [In Serbian].

Jovičić, J. (2010). Understanding of the position of the homeless in the EU countries, BA`s thesis. Beograd: Filozofski fakultet Univerziteta u Beogradu[In Serbian].

Lazić, M. (2011).Awaiting for Capitalism.Beograd: Službeni glasnik. [In Serbian]

Ljubičić, M. (2019).Working at a shelter for homeless people: researching employees' self-perceptio, Sociologija, LX (4), 818-836, https://doi.org/10.2298 SOC1804818L[In Serbian]

Ljubičić,M. (2013)Socio-pathological profile and treatment of persons placed in penitentiary psychiatric hospital for treatment and care, doctoral dissertation. Beograd: Filozofski fakultet Univerziteta u Beogradu. Available athttp://nardus.mpn.gov.rs/bitstream/ handle/123456789/3298/Disertacija.pdf?sequence=1\&isAllowed=y In Serbian].

Milić, A. et al. (1981).Marriage, Family and Household in Yugoslavia. Beograd: Institut za sociološka istraživanja Filozofskog fakulteta u Beogradu[In Serbian].

Nikitović, V. (2015).Migrants population.In V. Nikitovic (ed.) Population of Serbia at the Beginning of 21st Century, 98-103. Beograd: SORS. [In Serbian].

Penev, G. (2015).Population Structure by Age and Gender.In V. Nikitovic (ed.) Population of Serbia at the Beginning of 21st Century, 130-168. Beograd: SORS. [In Serbian].

Petrović, M.(2004).Sociology of Housing: Housing Policy Between Challenges and Possibilities). Beograd: ISI FF i Čigoja štampa [In Serbian].

Radivojević, B. (2015). Economic structures of the population.In V. Nikitovic (ed.) Population of Serbia at the Beginning of 21st Century, 222-264. Beograd: SORS.[In Serbian].

SORS (Statistical Office of the Republic of Serbia), (2013) Religion, Mother Tonge and Ethnicity, Beograd.

SORS (Statistical Office of the Republic of Serbia), (2011). Organizational and methodological instructions for the enumeration of the primary homeless. Beograd.

Stanković, B. (2015). Marital structures of the population. In V. Nikitovic (ed.) Population of Serbia at the Beginning of 21st Century, 194-222. Beograd: SORS.[In Serbian].

Šobot, A. (2015). Educational structure of the population. In V. Nikitovic (ed.) Population of Serbia at the Beginning of 21st Century, 68-194. Beograd: SORS. [In Serbian].

Timotijević, M. (2012). Homelessness in transformation. Contribution to the integral understanding of homelessness in Serbia, Socijalna misao(4), 41-53. [In Serbian].

Tomanović, S. et al.(2014).Single-parent families in Serbia. Sociological study. Beograd: Institut za sociološka istraživanja Filozofskog fakulteta.[In Serbian]. 
Žarković, B. Petrović, M. and Timotijević, M. (2012), Without a house, without a home. Results of the research of homelessness in Serbia. Beograd: HOUSING CENTRE, DISC, Developing Initiatives, Supporting Communities,UK [In Serbian],

Internet resources:

[ETHOS] https://www.feantsa.org/en/toolkit/2005/04/01/ethos-typology-on-

homelessness-and-housing-exclusion (28.09.2019).

https://www.feantsa.org/en/about-us/faq(8.10.2019).

http://www.kirs.gov.rs/wb-page.php?kat_id=34 (30.10.19.) 


\section{APPENDIX / ПРИЛОЗИ}

Графикон 1: Секундарни бескућници по старости и полу, Република Србија, Попис становништва 2011. (\%)

Figure 1: Secondary homeless by age and gender, Republic of Serbia, the 2011 Census (\%)

НАЗАД

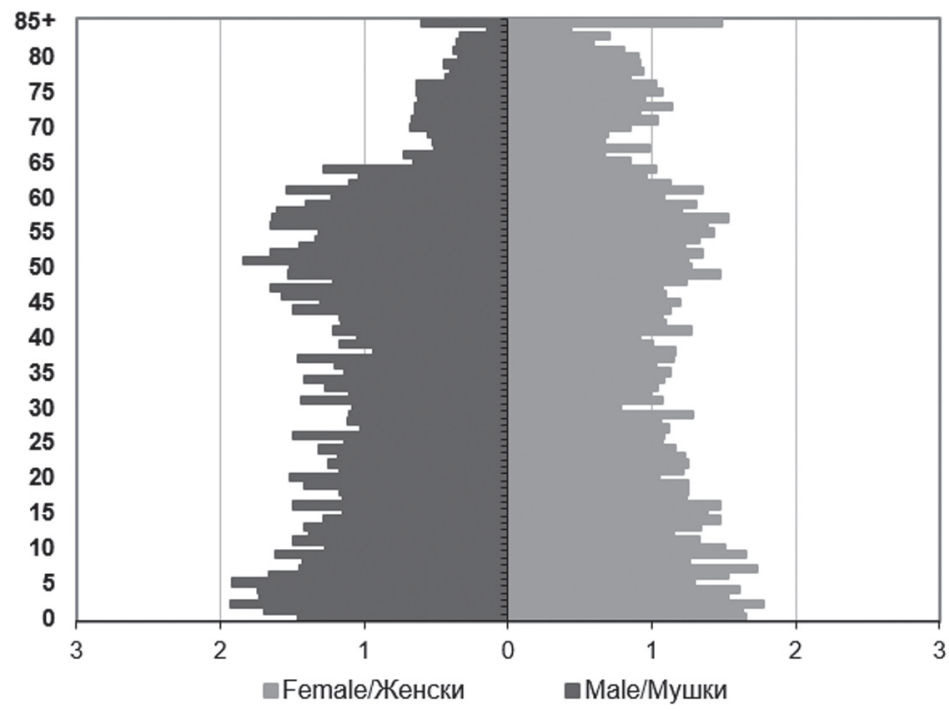

Извор: Прорачун ауторке / Source: Author's calculations

Графикон 2: Секундарни бескућници стари 15 и више година према законском брачном стању и полу, Република Србија, 2011, (\%).

Figure 2: Secondary homeless, 15+, by legal marital status and gender, Republic of Serbia, 2011, (\%).

Male/Мушки

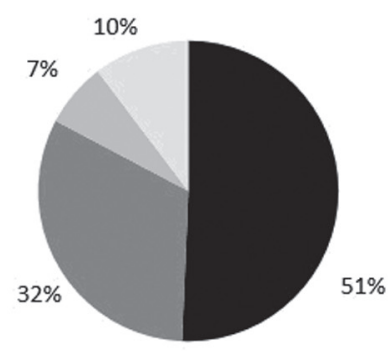

Female/Женски

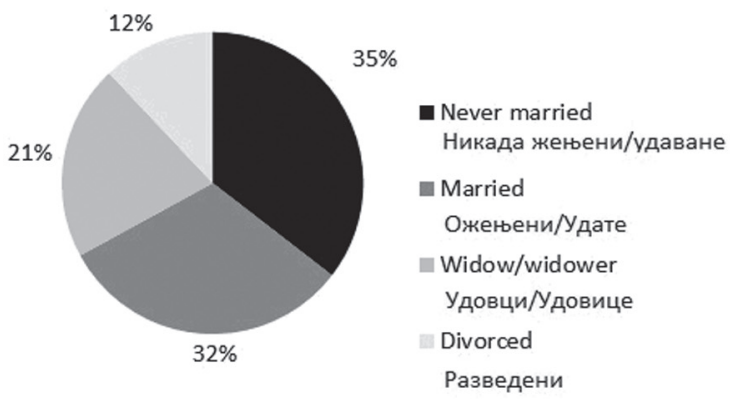

Извор: Прорачун ауторке / Source: Author’s calculations 
Графикон 3: Секундарни бескућници стари 15 и више година према школској спреми и полу, Република Србија, 2011.

Figure 3: Secondary homeless aged 15 and over by educational attainment and sex, Republic of Serbia, 2011
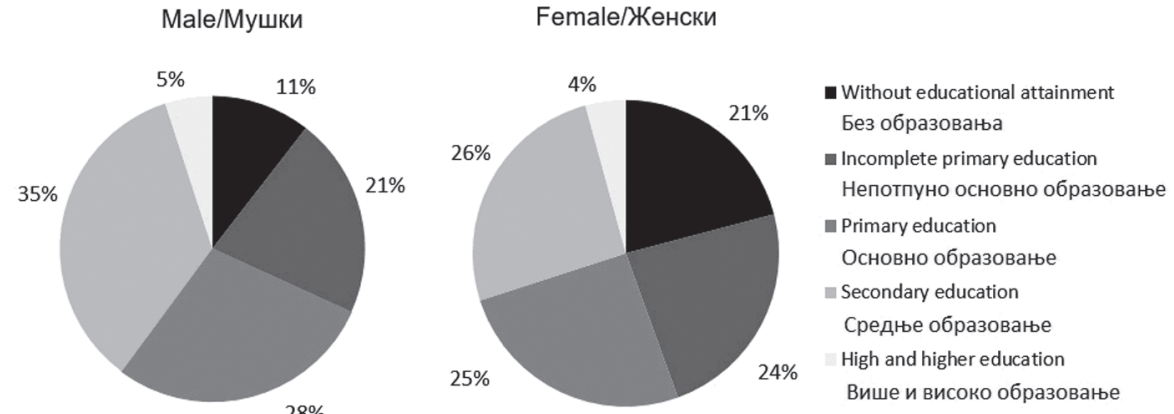

Извор: Прорачун ауторке / Source: Author's calculations

Графикон 4. Бескућници, приказ према занимању и полу, 2011 (\%)

Figure 4. Homeless, breakdown by occupation and gender, 2011 (\%)

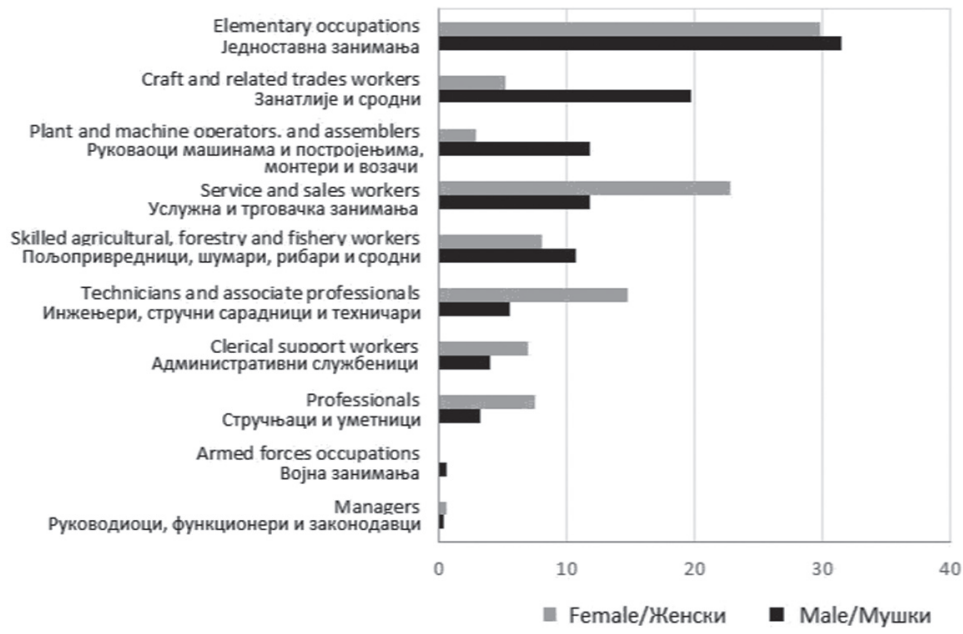

Извор: Прорачун ауторке / Source: Author's calculations 